Pak. j. sci. ind. res. Ser. A: phys. sci. 2021 64A(3) 240-246

\title{
Geology, Geochemistry and Petrographic Studies of Exposed Rock Units from Zhob and Qila Saifullah Districts of Balochistan
}

\author{
Hafiz Muhammad Zulfiqar Ali*, Muhammad Irfan Zubair, Hassan Ali, \\ Ghulam Akbar and Adnan Alam Awan \\ Geological Survey of Pakistan, Sariab Road, Quetta, Balochistan, Pakistan
}

(received December 12, 2019; revised September 15, 2020; accepted October 8, 2020)

\begin{abstract}
Present research exertion provides the information about the stratigraphy, geological structure, geochemistry and petrographic characteristics of the exposed sedimentary rock units and igneous intrusions around Zhob and Qila Saifullah districts of Balochistan. Sedimentary deposition in this area is attribute to both Pashin basin and Suleiman basin. The litho-stratigraphic sections of Suleiman basin are Spingwar formation and Loralai formation (Allozai Group) of Jurassic age and Goru formation, Parh limestone and Pab sandstone of Cretaceous age, whereas Pashin basin comprises of Nisai formation of Eocene age and Multana formation of Oligocene - Miocene age. The structural features of the area are comprising of complex, doubly plunging, anticlines and synclines which have been truncated by reverse faults at different places.

Geochemical analysis (X-Ray diffraction and X-Ray fluorescence) displays that Igneous Intrusions are comprising of Clay, Mica, Plagioclase and Spinal mineral with abundance of $\mathrm{Al}_{2} \mathrm{O}_{3}$ (11-14\% wt.), $\mathrm{SiO}_{2}$ (27-34 \% wt.), $\mathrm{CaO}$ (6-17\% wt.) and $\mathrm{Fe}_{2} \mathrm{O}_{3}$ (19-32\% wt.), whereas sedimentary rocks are rich in Quartz, Calcite and Albite with abundance of $\mathrm{Al}_{2} \mathrm{O}_{3}$ (0-17\% wt.), $\mathrm{SiO}_{2}(1.35-78 \%$ wt.), $\mathrm{CaO}(0.92-55 \%$ wt.) and $\mathrm{Fe}_{2} \mathrm{O}_{3}(0.07-13 \%$ wt.).

The petrographic studies of the carbonates indicate mudstone to wackstone, carbonate fabric with skeletal grains of Alveolina, Miliolids, Globotrancana, Algae, Stylolites and foraminifera, whereas the sandstone samples are rich in sub rounded to rounded quartz grain, feldspar and mica. Petrographic analysis of igneous intrusion shows muscovite, pyroxene needles, chlorite and opaque minerals. Economically the research area is appropriate for cement factory, glass industry and building stones.
\end{abstract}

Keywords: 39 F/1 Quadrangle, geochemistry, stratigraphy, petrography, Balochistan

\section{Introduction}

The study area lies under the Survey of Pakistan (SoP) Toposheet \# $39 \mathrm{~F} / 1$, the Simzai quadrangle and covers $30^{\circ} 45^{\prime} 00^{\prime \prime} \mathrm{N}$ to $31^{\circ} 0^{\prime} 00^{\prime \prime} \mathrm{N}$ and $69^{\circ} 0^{\prime} 00^{\prime \prime} \mathrm{E}$ to $69^{\circ}$ $15^{\prime} 00^{\prime \prime}$ E along the Qila Saifullah to Zhob road (N-50). This work delivers the general stratigraphy, geochemistry and petrographic characteristics of the uncovered rock units of the region. The landscape of the area generally comprising valleys, mountain ranges and alluvium deposits. Highest and lowest elevation the area is 6385 and 4700 feet, respectively. Main streams and Nalas of the area are Gang nala, Kandil rud, Zhob river, Tasmoz shela, Gardai nala, Gwai karez, Ghazlai rud, Akhun shela, Gat shela and Barak shela. Digitized geological map of $39 \mathrm{~F} / 1$ on the $1: 50,000$ scale is available at Publication Directorate, Geological Survey of Pakistan, Headquarter Office Quetta.

*Author for correspondence;

E-mail: hzpakgeologist@gmail.com
Geological setting. During late Triassic, rifting along the northern margin of Gondwanaland produced Cimmerian micro continents (Afghan Block, Tibat Blocks etc.) that collided with Eurasian plate by late Cretaceous (Searle, 1991). While the Indo-Madagascar Plate separated from the African and Australian plate during early cretaceous (Khan et al., 2007; Peters, 2000) and Indian ocean began to developed. Generalized tectonic evolutionary model after (Kerr et al., 2016; Treloar and Izat, 1993) for collision between Indian continent and Afghan block, tectonic evolution of Pishin basin and obduction of ophiolites on northwestern margin of Indian plate is illustrated in Fig. 1.

During late Cretaceous Indian plate separated from Madagascar is resulting in development of an oceanic spreading centre. A short lived intra-oceanic subduction zones was formed due to the rotation and transpression along the northwestern margin of Indian continent. 


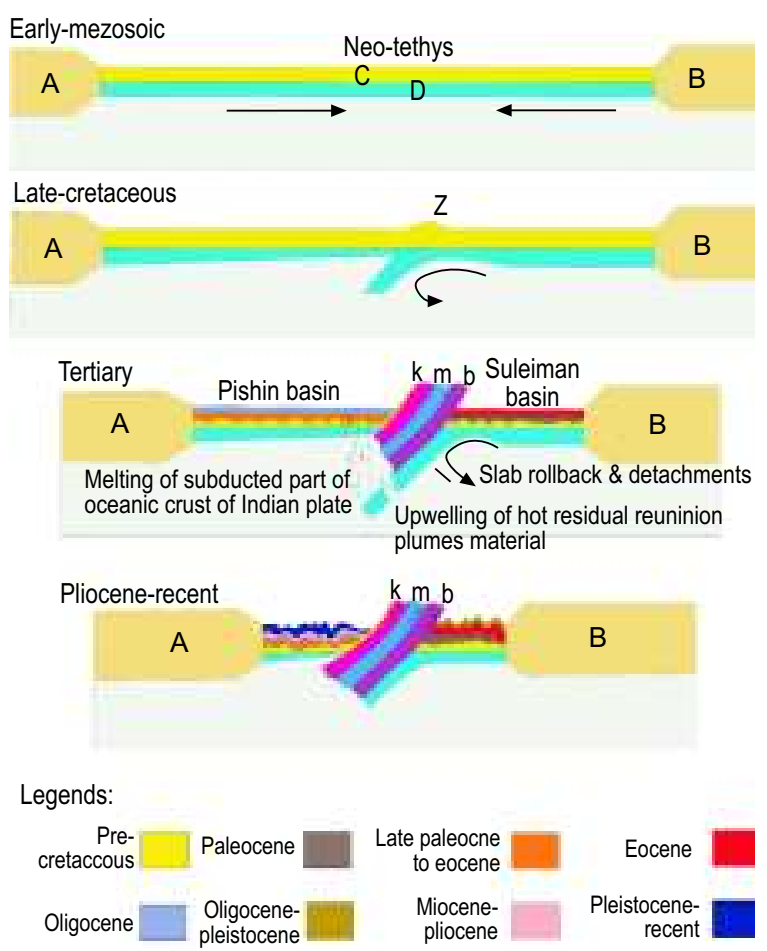

Fig.1. Generalized tectonic evolutionary model from Traloar and Izzat (1993) and Kerr et al. (2016) after modification: (A) = Afghan block; $(\mathrm{B})=$ Indian plate; $(\mathrm{C})=$ Pre-cretaceous extension of Neo-tethys sediments; (D) = Oceanic crust separating two continental blocks; $(Z)=$ Subduction zone of Indian oceanic crust beneath Afghan block, whereas: (b) = Bagh-Zhob ophiolites; $(\mathrm{m})=$ Muslim bagh ophilites and $(\mathrm{k})=$ khanozai ophilites. The short-lived suprasubduction of Indian continent and its transpressional rotation give rise to three types of ophilites.

During Triassic to Cretaceous period, a broad carbonate platform developed on the southwestern margin of the Indian plate, where the sediments of Suleiman and Kirther fold belt were deposited. As the continued northward movement of Indian plate and its subduction beneath under Eurasian plate resulted in obduction of Bagh ophiolites, Muslim Bagh ophiolites and Khanozai ophiolites and Volcanic arc complex of Nuristan and Chagai (Treloar and Izatt, 1993).

These ophiolites sequences along with volcanic arc separates the newly formed back arc basin from the Suleiman foredeep basin. The oceanic crust of the Indian plate bent downward due to flexural loading beneath
Afghan block that commenced clastic deposition and formed Pishin basin (Searle, 1987). The Indian plate eventually collided with Afghan block in Pliocene at highly oblique angle (Treloar, 1993).

\section{Material and Methods}

Oriented samples of sedimentary rocks and igneous intrusion exposed at different localities were collected for further laboratory works. Petrography, nine thin sections of the oriented field samples from exposed rock units of the area studied under microscope, exclusive in Plate $(1)=$ work done in the laboratory of PetMin Directorate at GSP Headquarter office Quetta. $\mathrm{X}$-ray diffraction (XRD) and X-ray fluorescence (XRF) techniques for geochemical analysis of both sedimentary and igneous intrusions were used in the Geoscience Advance Research Laboratories (GARL) Islamabad.

Stratigraphy. Stratigraphically, the area consists of two basins i.e., Suleiman basin and Pishin basin. The Suleiman basin is part of Indus basin and characterized by Jurassic to Oligocene marine and transitional marine sediments of Tethys realm (Malkani, 2010; Jadoon et al., 1994; Bannert et al., 1989).

The Pishin basin (Ahmed el at., 1991) also referred as Kakar Khurasan basin (Kazmi and Jan, 1997) comprises of eocene to Pleistocene sediments and has been evolved as a back arc basin due to convergence of Indian plate and Afghan block (Jadoon and Khurshid, 1996; Lawrence et al., 1981). The observed stratigraphy of the area is given in Table 1.

\section{Results and Discussion}

Stratigraphically, the investigated area starts from Jurassic to recent and the structural features of the area comprising of doubly plunging anticlines and synclines which have been truncated by reverse faults at different places.

Geological structure. Structurally, the area (39F/1) has very complex geometry and comprises of tight and overturned anticlines, relatively broad and doubly plunging synclines and low to high angle thrust fault. Most of the structure trending SW-NE and E-W direction.

The main folds observed in research area are Simzai syncline, Ware syncline, Shakh killi syncline, Ghumbar ghar syncline, Tang Haiderzai syncline, Pewar anticline, Barak anticlines, Uzgi anticline, Tor ghar anticline, 
Table 1. Stratigraphy of exposed rock units from Zhob and Qila Saifullah

\begin{tabular}{|c|c|c|c|}
\hline Period & Epoch & Formation & Lithology \\
\hline \multirow[t]{3}{*}{ Quaternary } & Recent & & Loose gravel with sand, silt and clay \\
\hline & Sub recent & & Gravel, sand, silt and clay (Semi consolidated to lose) \\
\hline & \multicolumn{3}{|c|}{ Angular unconformity } \\
\hline \multirow[t]{3}{*}{ Tertiary } & Miocene & Multana formation & Sandstone interbedded with siltstone, mudstone \& conglomerate \\
\hline & Eocene & Nisai formation & Fossiliferous limestone \\
\hline & \multicolumn{3}{|c|}{ Disconformity } \\
\hline \multirow[t]{4}{*}{ Cretaceous } & Upper & Pab sandstone & Quartzose sandstone, minor marl and argillaceous limestone \\
\hline & Middle & Parh limestone & Mainly limestone with minor shale \\
\hline & Early & Goru formation & Marl, Shale and limestone \\
\hline & \multicolumn{3}{|c|}{ Disconformity } \\
\hline \multirow[t]{2}{*}{ Jurassic } & Early to middle Jurassic & Loralai formation & High peaks of limestone with minor shale and marl \\
\hline & Early Jurassic & Spingwar formation & Low lying mounds of limestone with interbedded shale and marl \\
\hline
\end{tabular}

Akhun shela anticline, Nishpa anticline, Tsamoz anticline and Sharan killi anticline (field photograph).

Whereas, Zhob valley thrust is the major one but concealed by recent alluvium deposits and has been observed only in northwestern side of the research area, where the Oligocene sediments (Multana formation) were thrusted over Cretaceous sediments (Parh limestone). Thus, this thrust fault is marked as boundary line between Pishin basin and Suleiman basin.

Petrography. For this purpose, nine (9) different samples were selected for the petrographic work to identify the fossil and mineral assemblages in the exposed sedimentary rocks of research area. Thin sections were prepared from the Petrology and Mineralogy Directorate Laboratories at GSP headquarter office Quetta, where standard method was followed. Each thin section was interpreted under Leica electron microscope by Leica application suit LAS Core, under 2.5X lens in crossed Nicole and plane polarized light. All petrological features are captioned in Plate 1.

Geochemical analysis. The geochemical analysis (XRD \& XRF) of 11 samples were carried out (4 from igneous intrusions and 7 from exposed sedimentary rocks) from different localities. Igneous intrusions were observed in the form of sills/massive intrusive and these igneous bodies are related to Zhob valley ophiolites and exhibits layering in texture and compositions (field photographs).

Most of these intrusions have dark green to olive black green colour and vary in thickness from 1-8 M.
Some intrusions have shining surfaces which reflect the light and give bright luster. These igneous body contains the crystals of pyroxene of different sizes. One major igneous intrusion exposed as isolated body near Musafirpur levies station and Shakh killi.

Geochemical analysis (XRD) of igneous intrusion indicates three main group of minerals (Table 2) which are present in the samples collected from the area such as:

Clay group (Chlorite, Illite and Montmorillonite), Mica group (Biotite) and Plagioclase group (Albite).

$\mathrm{XRF}$ analysis of igneous intrusion (Table 3) shows that the analyzed samples are near to chromite (hercynite) which is iron aluminum oxide however the chromite contains three main types which are iron chromium oxide, magnesium chromium oxide and iron aluminum oxide.

The results of geochemical analysis indicate that igneous intrusions (Table 2 and 3) are containing of clay, mica, plagioclase and spinal mineral with abundance of $\mathrm{Al}_{2} \mathrm{O}_{3}$

Table 2. XRD results of igneous intrusion

\begin{tabular}{ll}
\hline \hline Sample & Identified minerals \\
\hline Igneous intrusion sample 1 & Chlorite, Serpentine, Albite \\
Igneous intrusion sample 2 & Albite, Biotite, Analcime \\
Igneous intrusion sample 3 & $\begin{array}{l}\text { Albite, Calcian, Montmoril- } \\
\text { lonite, Analcime }\end{array}$ \\
Igneous intrusion sample 4 & Illite, Lepidolite, Albite \\
\hline \hline
\end{tabular}


Table 3. XRF Results of Igneous intrusion (wt. \%)

\begin{tabular}{lllll}
\hline \hline Sample & $\begin{array}{l}\text { Igneous intrusion } \\
\text { sample 1 }\end{array}$ & $\begin{array}{l}\text { Igneous intrusion } \\
\text { sample 2 }\end{array}$ & $\begin{array}{l}\text { Igneous intrusion } \\
\text { sample 3 }\end{array}$ & $\begin{array}{l}\text { Igneous intrusion } \\
\text { sample 4 }\end{array}$ \\
\hline Sodium oxide & 2.27 & 2.41 & 2.12 & 1.10 \\
Magnesium oxide & 2.26 & 2.46 & 2.21 & 4.77 \\
Aluminum oxide & 11.17 & 13.28 & 14.36 & 11.27 \\
Silica & 27.80 & 32.70 & 34.11 & 27 \\
Potassium oxide & 1.23 & 2.52 & 2.96 & 2.36 \\
Calcium oxide & 17.22 & 8.30 & 6.45 & 8.26 \\
Titanium oxide & 2.84 & 2.65 & 2.59 & 3.38 \\
Iron oxide & 21.11 & 19.78 & 19.48 & 32 \\
LOI & 11.43 & 12.97 & 13.38 & 6.40 \\
\hline \hline
\end{tabular}
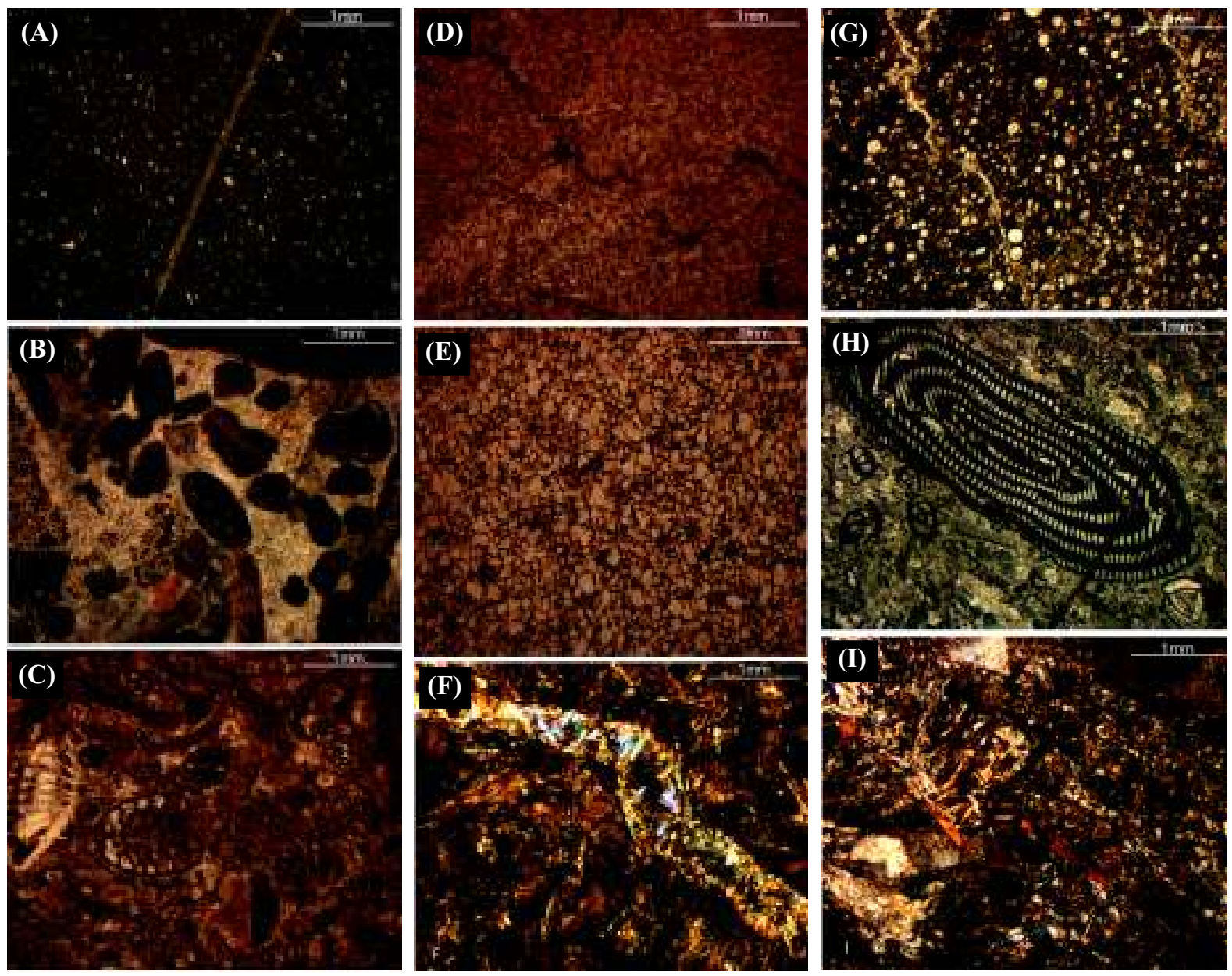

Plate 1. where $(\mathrm{A})=$ veins filled with calcite material and fossil content; $(\mathrm{B})=$ cemented carbonate clast and calcite cement as ground mass; $(\mathrm{C} \& \mathrm{H})=$ alveolina, miliolids, foraminifera and algae; $(\mathrm{D})=$ stylolite (pressure solutions) opaque mineral (ferromagnesian material); $(\mathrm{E})=$ quartz grains and opaque mineral (ferromagnesian material); (F\&I) = muscovite, pyroxene needles, chlorite, opaque mineral (ferromagnesian material) and carbonate mud; $(\mathrm{G})$ = carbonate mud, globotruncana species and veins filled with calcite material (Adams et al., 1984). 
(11-14\% wt.), $\mathrm{SiO}_{2}$ (27-34\% wt.), $\mathrm{CaO}$ (6-17\% wt.) and $\mathrm{Fe}_{2} \mathrm{O}_{3}(19-32 \%$ wt.).

Geochemical analysis (XRD) of exposed sedimentary rocks shows quartz, calcite and clay minerals in the collected oriented samples (Table 4). XRF analysis
(Table 5) of exposed sedimentary rocks displays four major elements as $\mathrm{SiO}_{2}$ (1.35 to 78 wt. \%), $\mathrm{CaO}(0.92$ to 55 wt. \%), $\mathrm{Al}_{2} \mathrm{O}_{3}$ (0 to 17 wt. \%) and $\mathrm{Fe}_{2} \mathrm{O}_{3}(0.07$ to 13 wt. \%), whereas $\mathrm{TiO}_{2}, \mathrm{Mn}_{2} \mathrm{O}_{3}, \mathrm{~K}_{2} \mathrm{O}, \mathrm{SrO}$ and $\mathrm{ZrO}_{2}$ are present as minor elements.

Table 4. XRD Results of exposed sedimentary rocks

\begin{tabular}{|c|c|c|}
\hline Formation & Identified minerals & Collected field samples \\
\hline Pab sandstone (with solid varnish) & Quartz, Calcite, Albite & \\
\hline Pab shale (chocolate colour) & Quartz, Illite & \\
\hline Parh limestone & Calcite Magnesium & \\
\hline Goru formation (pencil resembling) & Quartz, Calcite, Albite, Calcian & \\
\hline Goru formation (shale) & Quartz, Calcite magnesium & \\
\hline Nisai limestone & Calcite magnesium & \\
\hline Multana sandstone & Quartz, Calcite magnesium & \\
\hline
\end{tabular}


Table 5. XRF Results of exposed sedimentary rocks (wt. \%)

\begin{tabular}{|c|c|c|c|c|c|c|c|}
\hline \multirow[t]{2}{*}{ Major element } & \multicolumn{7}{|c|}{ Field rock sample } \\
\hline & $\begin{array}{l}\text { Pab sandstone } \\
\text { (with solid varnish) }\end{array}$ & $\begin{array}{l}\text { Pab shale } \\
\text { (chocolate colour) }\end{array}$ & $\begin{array}{l}\text { Goru formation } \\
\text { (pencil resembling) }\end{array}$ & $\begin{array}{l}\text { Parh } \\
\text { limestone }\end{array}$ & $\begin{array}{l}\text { Goru formation } \\
\text { (shale) }\end{array}$ & $\begin{array}{l}\text { Nisai } \\
\text { formation }\end{array}$ & $\begin{array}{l}\text { Multana } \\
\text { sandstone }\end{array}$ \\
\hline Silica & 78.59 & 51.28 & 62.08 & 4.03 & 59.77 & 1.35 & 60.78 \\
\hline Calcium oxide & 7.57 & 0.92 & 7.76 & 53.4 & 8.56 & 55.89 & 22.72 \\
\hline Titanium oxide & 0.37 & 2.02 & 1.25 & 0.08 & 1.11 & 0.00 & 0.00 \\
\hline Manganese oxide & 0.35 & 0.00 & 0.27 & 0.39 & 0.39 & 0.01 & 0.28 \\
\hline Aluminum oxide & 4.71 & 17.68 & 9.26 & 1.11 & 9.76 & 0.00 & 0.00 \\
\hline Iron oxide & 5.02 & 13.8 & 8.78 & 0.81 & 7.92 & 0.07 & 0.07 \\
\hline Potassium oxide & 0.23 & 5.55 & 1.82 & 0.02 & 2.79 & 0.2 & 5.69 \\
\hline Strontium oxide & 0.02 & 0.04 & 0.03 & 0.04 & 0.02 & 0.00 & 0.00 \\
\hline Zirconium oxide & 0.04 & 0.07 & 0.04 & 0.00 & 0.03 & 0.00 & 0.01 \\
\hline LOI & 3.11 & 8.59 & 8.64 & 40.11 & 9.55 & 41.7 & 10.1 \\
\hline
\end{tabular}
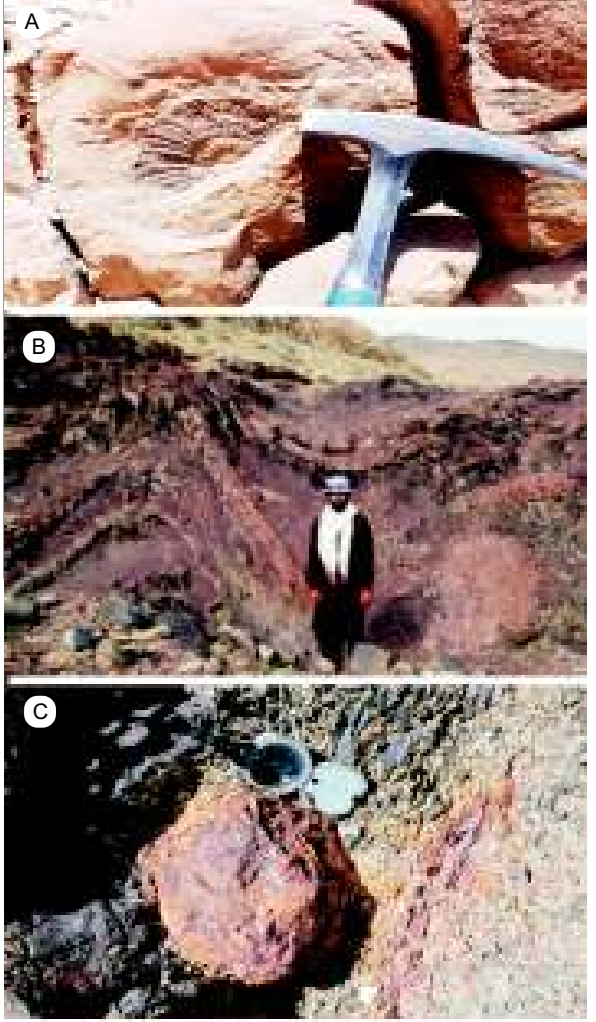

D

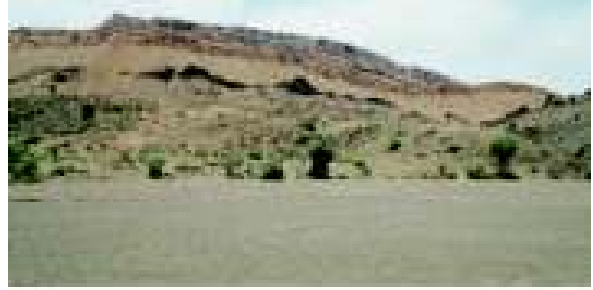

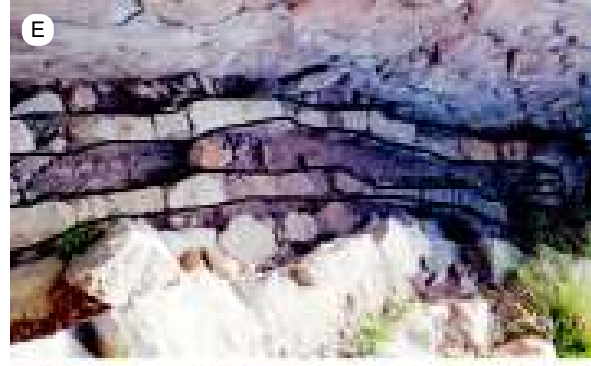
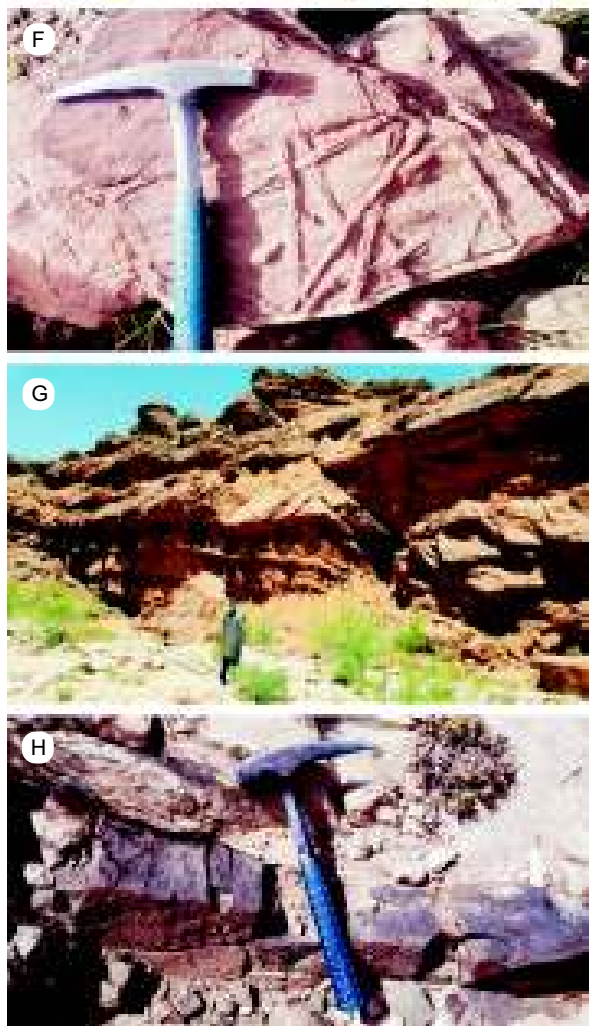

Field photographs. $A=$ Ammonite embedded in the limestone of spingwar formation; $(B)=$ Intense folding in goru formation; (C) = Iron and phosphatic nodules in goru formation; (D) = Whole succession of cretaceous with igneous intrusion on $39 \mathrm{f} / 1 ;(\mathrm{E})=$ Recumbent fold in parh limestone; $(\mathrm{F})=$ Burrows and tracks in pab sandstone; $(\mathrm{G})=$ Intra formational reverse fault in multana formation and $(\mathrm{H})=$ Igneous intrusion along the bedding of parh limestone. 


\section{Conclusions and Recommendations}

- Research area falls in the transpressional regime and due to the oblique convergence of Indian plate with Eurasian plate Sulaiman lobe has formed that contains thick sequence of carbonate rocks. Due to transpressional tectonics, the project area has many anticlines, plunging synclines, doubly plunging synclines, intraformational faults, some thrusted and faulted contacts.

- The investigated area is comprised of Mesozoic sequence in the northeast, southeast and southwest and tertiary sequence in the northwest. These sequences are composed of variegated lithology's like limestone, sandstone, siltstone, shale, marl, conglomerates and quaternary deposits. Generally, the Calcite mineral is found in abundance in the project area. Some showings of iron oxide, pyrite and phosphate is also found in the project area. Volcanic / igneous intrusions from 2-8 $\mathrm{M}$ are also present at different places (field photographs)

- The quartzose sandstone of Pab formation may be used in Glass Industry as silica sand is present in the Pab sandstone just like the silica sand of Datta formation in western Salt Range which is being utilized for this purpose.

- Igneous intrusions may also play vital role as it hosts many precious metals e.g. chromite etc. in the research area.

- As CPEC route also passes through project area so it has great importance regarding limestone and sandstone that is present in huge quantity. Limestone may be used as aggregate for construction purposes. Sandstone is typically used as flooring or paving materials.

Conflict of Interest. The authors declare no conflict of interest.

\section{References}

Ahmed, R. 1991. Pishin basin: status and prospects. Pakistan Journal of Hydrocarbon Research, 6: 718.

Adams, A.E., McKenzie, W. S., Guilford, C. 1984. Atlas of sedimentary rocks under the microscope. Longman Scientific and Technical, 1: 40-92.

Bannert, D., Cheema, A., Ahmed, A. 1989. Interpretation of LANDSAT-MSS imagery of the Sulaiman and Kirthar ranges in western Pakistan. HDIP-BGR Internal Report, 83: 12-25.

Jadoon, I.A., Khurshid, A. 1996. Gravity and tectonic model across the Sulaiman fold belt and the Chaman fault zone in western Pakistan and eastern Afghanistan. Tectonophysics, 254: 89-109.

Jadoon, I.A., Lawrence, R.D., Lillie, R.J. 1994. Seismic data, geometry, evolution and shortening in the active Sulaiman fold-and-thrust belt of Pakistan, southwest of the Himalayas. AAPG Bulletin, 78: 758-774.

Khan, S.D., Mahmood, K., Casey, J.F. 2007. Mapping of Muslim bagh ophiolite complex (Pakistan) using new remote sensing and field data. Journal of Asian Earth Sciences, 30: 333-343.

Kerr, A.C., Lavis, O., Kakar, M.I., McDonald, I. 2016. Petrogenesis and tectonomagmatic significance of Eocene mafic intrusions from the Neotethyan suture zone in the Muslim Bagh-Khanozai region, Pakistan. Journal of the Geological Society, 173: 518-530.

Kazmi, A.H., Jan, M.Q. 1997. Geology and Tectonics of Pakistan. Graphic Publisher, 1: 554-260.

Lawrence, R.D., Yeats, R.S., Khan, S.H., Farah, A., DeJong, K.A. 1981. Thrust and strike slip fault interaction along the Chaman transform zone, Pakistan. Geological Society, London. Special Publications, 9: 363-370.

Malkani, M.S. 2010. Updated stratigraphy and mineral potential of Sulaiman basin, Pakistan. Sindh University Research Journal-SURJ (Science Series), 43: 17-27.

Peters, T. 2000. Masirah, the other Oman ophiolite: A better analogue for mid-ocean ridge processes. Geoscience Frontiers, 1: 5-14.

Searle, M.P. 1991. Geology and Tectonics of the Karakoram Mountains, John Wiley and Sons Incorporated, 1: 26-38.

Searle, M.P. 1987. Structural evolution and sequence of thrusting in the high Himalayan, Tibetan-Tethys and Indus suture zones of Zanskar and Ladakh, western Himalaya. Journal of Structural Geology, 8: 923-936.

Treloar, P.J., Izatt, C.N. 1993. Tectonics of the Himalayan collision between the Indian plate and the Afghan block: A synthesis. Geological Society, London, Special Publications, 74: 69-87. 